\title{
IL1R2 Gene
}

National Cancer Institute

\section{Source}

National Cancer Institute. IL1R2 Gene. NCI Thesaurus. Code C38913.

This gene plays a role in the modulation of lig and interactions and cytokine regulation. 